\title{
MODEL DAN STRATEGI PENYUNTINGAN DAN PENERBITAN DI SOLOPOS SEBAGAI PENOPANG EKSISTENSI PENULIS INDONESIA
}

\author{
Achmad Bashori \\ Pendidikan Bahasa Indonesia, Universitas Sebelas Maret \\ Jalan Ir. Sutami No.36A, Jebres, Surakarta, Jawa Tengah \\ Surel: achmadbashori03.ab@student.uns.ac.id
}

\begin{abstract}
ABSTRAK
Artikel ini penulis dapatkan pada Harian Umum Solopos yang bertempat di Jl. Adi Sucipto, Karangasem, Laweyan, Kota Surakarta, Jawa Tengah. Subjek dalam penelitian ini adalah Harian Umum Solopos, sedangkan objeknya berita-berita langsung yang telah melewati proses seleksi dan penyuntingan. Adapun yang menjadi populasi dalam penelitian ini adalah berita-berita langsung (straight news) yang ada di Harian Umum Solopos. Sampel yang diambil meliputi keseluruhan isi berita langsung mulai dari judul, lead, sampai pada isinya pada edisi yang dimaksud secara acak. Teknik yang penulis gunakan untuk mencari data dalam penulisan artikel ilmiah ini adalah wawancara, studi literatur, dan observasi.
\end{abstract}

Kata kunci: penulis, artikel, penyuntingan

\section{ABSTRACT}

This article the author gets on Solopos Public Daily which is located at Jl. Adi Sucipto, Karangasem, Laweyan, Surakarta City, Central Java. The subjects in this study were Solopos General Daily, while the objects were direct news that had passed the selection and editing process. As for the population in this study is the direct news (straight news) that is in the Daily General Solopos. Samples taken include the entire contents of the news directly starting from the title, lead, to the contents in the intended edition at random. The technique that I use to find data in writing scientific articles is interviews, literature studies, and observations. Keywords: writer, article, editing 


\section{PENDAHULUAN}

Dewasa ini informasi bukan lagi sebagai kebutuhan, tetapi juga telah menjadi komoditi masyarakat luas. . Kehausan masyarakat akan informasi tidak dapat disangkal lagi dan peran wartawan sebagai pembuat berita telah menempati posisi yang amat penting dalam kehidupan sehariharinya. Apalagi Pers sebagai lembaga kemasyarakatan yang bergerak dalam bidang pengumpulan dan penyebaran informasi tentunya memiliki misi ikut mencerdaskan kehidupan masyarakat.

Ini artinya, pers dituntut tidak hanya sekedar memberikan informasi semata, tetapi juga harus benar dalam penyajiannya dan tidak melanggar kode etik jurnalistiknya serta tidak menimbulkan makna ganda atau kalimat yang rancu. Sehingga pers tidak dianggap menyesatkan atau salah diartikan oleh pembacanya.

Semua ini tentunya dapat memberikan pelajaran bagi setiap surat kabar agar selalu menyajikan berita-berita yang tidak hanya sekedar cepat dan akurat saja tetapi juga harus memperhatikan gaya penulisan yang mengacu ke dalam ejaan bahasa Indonesia yang baik dan benar.

Selain itu, yang harus diperhatikan oleh setiap media massa terutama media cetak adalah pada proses penyuntingan sebuah berita, sebelum berita itu dipublikasikan kepada khalayak ramai. Dalam posisi ini biasanya dipegang oleh seorang redaktur (penyunting berita). Melalui redaktur inilah berita tidak hanya enak dibaca tetapi juga harus menggunakan bahasa yang baku dan sesuai dengan bahasa jurnalistik. Bahkan, seorang redaktur tidak hanya dituntut untuk pandai memilih katakata tetapi juga dituntut harus memiliki pengetahuan yang luas dibidang jurnalistik, khususnya dalam bidang bahasa. Bahasa menjadi alat rekam gagasan dan ide-ide yang dilakukan oleh orang terdahulu. Bentuk bahasa yang menjadi alat rekam menjadikan bahasa sebagai budaya yang dapat dipelajari sampai saat ini (Arifa Ainun Rondiyah dkk, 2017:144).

Kecakapan seorang redaktur dalam memilih kata-kata sangat menentukan menarik tidaknya sebuah surat kabar, baik dari segi bahasa, susunan 
kalimatnya maupun keakuratan dari berita tersebut. Maka tidak salah jika Dja'far H. Assegaff, dalam bukunya Jurnalistik Masa Kini (1983:69) menuliskan salah seorang pendiri harian "New York Times" pernah mengatakan bahwa wartawan yang paling berguna adalah wartawan yang pandai menyunting berita (mengedit berita).

Pada dasarnya penyuntingan berfungsi membantu penulis untuk menyampaikan idenya kepada pembaca. Oleh karena itu, se- belum memulai menyunting sebaiknya penyunting memahami betul isi teks yang disuntingnya (Kartika Pandu Latsiya dkk, 2016:43). Setiap kata dan kalimat selain harus benar ejaan atau cara penulisannya, juga harus benar-benar punya arti dan enak dibaca.

Editor juga harus memperhatikan apakah isi tulisan itu dapat dan mudah dimengerti oleh pembaca atau malah membingungkan. Karena pada dasarnya sebuah penerbitan pers umumnya bergantung pada keahlian dan kreatifitas para redakturnya dalam teknik menyunting. Dalam bukunya Jurnalistik Praktis Untuk
Pemula, Asep Syamsul M. Romli (2005:68), kegiatan menyunting yang dilakukan oleh seorang redaktur/editor pada dasarnya mencakup hal-hal berikut :

1. Mencegah terjadinya salah ejaan dan struktur kalimat, kesalahan fakta, dan kesalahan pada struktur berita.

2. Memperbaiki kesalahan dalam penggunaan tanda baca, tata bahasa, dan ejaannya.

3. Menjaga jangan sampai terjadi penghinaan atau menimbulkan arti ganda, serta menghindarkan tulisan yang membosankan.

4. Membuang kata-kata yang mubazir dan memperhatikan ekonomi kata.

5. Menjaga jangan sampai masuknya berita yang sudah basi dan menghindari terjadinya kontradiksi dalam mengedit berita dan kemudian memperbaikinya.

6. Menyeleksi berita-berita yang masuk ke meja redaksi (meja redaktur).

Menurut A.M. Hoeta Soehoet (2002:4) penyuntingan berarti mengolah naskah berita menjadi copy berita dengan tujuan agar pembaca tertarik membacanya dan mudah dipahami. Oleh karena itu, proses 
editing mempunyai peran yang sangat penting dalam memproduksi sebuah surat kabar. Proses editing yang baik juga akan membuat produksi surat kabar yang mendekati sempurna. Selain itu, editing juga akan menentukan apakah sistematikanya logis atau tidak. Dengan demikian, seorang editor tidak hanya pandai memotong (cutting) berita agar masuk ke dalam kolom yang telah disediakan tetapi juga bagaimana membuat tulisan itu bisa menarik, enak dibaca dan berita yang diedit itu tetap berada pada konteks makna semula, tidak rancu dan tidak menyesatkan maknanya.

Tanggungjawab seorang editor sangat berat dan membawa resiko yang sangat besar jika terjadi kesalahan dalam pengeditannya, selain dituntut agar menggunakan bahasa yang efektif dan efesien sehingga dalam menyampaikan pesan yang dituliskan tidak "berbelit-belit". Juga harus berorientasi pada kepentingan pembaca jangan sampai berita yang ditulis itu hanya bisa dipahami oleh dirinya saja, tetapi membingungkan bagi pembacanya. Belum lagi, seorang redaktur terutama dalam media harian seperti Solopos mereka harus berlomba dengan waktu mengingat "date line" yang telah ditetapkan. Dengan waktu yang terbatas itu redaktur harus bertanggungjawab atas menarik tidaknya sebuah berita. Oleh karena itu, situasi ini sangat rawan sekali terjadinya kesalahan baik kesalahan tulis, ejaan maupun masuknya katakata mubazir.

Sebagai suatu keterampilan yang produktif dan ekspresif, keterampilan menulis tentu tidak mudah dikuasai oleh seseorang begitu saja. Dengan kata lain, jika seseorang ingin dapat memiliki keterampilan menulis yang baik, maka ia harus melewati tahaptahap atau proses menulis untuk menghasilkan tulisan yang bermutu (Nur Endah Ariningsih dkk, 2012:50).

Kegiatan menulis dapat bermanfaat bagi seseorang untuk mengungkapkan gagasan agar dibaca dan dipahami oleh pembaca. Dengan menulis, seseorang mampu mengungkapkan gagasan secara sistematis, jelas, logis, serta mampu berkomunikasi sesuai dengan konteks. Selain itu, melalui kegiatan 
menulis, gagasan yang diungkapkan dapat diketahui oleh banyak orang sehingga dapat bermanfaat bagi masyarakat luas (Dinari Oktaria dkk, 2017:166).

Melihat fenomena diatas penulis tertarik untuk membuat laporan akhir yang berjudul "MODEL DAN STRATEGI PENYUNTINGAN DAN PENERBITAN DI SOLOPOS SEBAGAI PENOPANG EKSISTENSI PENULIS

INDONESIA". Judul ini penulis pilih karena tulisan yang sama belum pernah dilakukan pada Harian Umum Solopos.

\section{METODE}

Artikel ini penulis dapatkan pada Harian Umum Solopos yang bertempat di Jl. Adi Sucipto, Karangasem, Laweyan, Kota Surakarta, Jawa Tengah. Penulis juga melakukan magang yang dimulai tanggal 7 Januari 2019 sampai 16 Februari 2019. Subjek dalam penelitian ini adalah Harian Umum Solopos, sedangkan objeknya beritaberita langsung yang telah melewati proses seleksi dan penyuntingan. Adapun yang menjadi populasi dalam penelitian ini adalah berita-berita langsung (straight news) yang ada di Harian Umum Solopos. Sampel yang diambil meliputi keseluruhan isi berita langsung mulai dari judul, lead, sampai pada isinya pada edisi yang dimaksud secara acak. Teknik yang penulis gunakan untuk mencari data dalam penulisan artikel ilmiah ini adalah:

1. Wawancara

Untuk melengkapi data-data yang diperlukan dalam membuat laporan ini, penulis juga melakukan wawancara (interview) dengan redaktur dan pihak-pihak terkait pada Harian Umum Solopos.

2. Studi Literatur

Yaitu melakukan studi pustaka dengan menelaah buku-buku dan dokumen yang diperlukan dalam penulisan laporan ini.

3. Hasil yang dikerjakan dilapangan / Observasi

Penulis juga mengambil data yang di dapat dari lapangan pada waktu peliputan dan penulisan berita yang telah diperintahkan dengan petunjuk pamong. 
Untuk menganalisa data dalam karya ilmiah ini penulis menggunakan metode deskriptif yaitu cara yang teratur untuk mengupas uraian sesuatu menurut apa adanya, berdasarkan pada data yang telah ada dengan memaparkan data tersebut untuk menjelaskan permasalahan yang diteliti.

\section{HASIL DAN PEMBAHASAN}

Jika penulis perhatikan secara seksama beberapa contoh naskah berita yang lolos seleksi dan yang telah dilakukan penyuntingan oleh Redaktur dan Redpel. Maka, betapa berat tugas yang harus diemban editor. Selain ditekan oleh waktu (datelinenya), editor juga harus berkorban dari segi tenaga dan fikirannya. Tenaga, karena editor bekerja dari sore sampai tengah malam bahkan hampir pagi. Dari segi fikiran karena, selain harus bagus dan menarik beritanya kaidah bahasa Indonesia dan susunan beritanya juga harus tepat.

Pada beberapa contoh yang penulis sajikan, ternyata masih banyak kesalahan-kesalahan yang penulis temukan dalam proses penyuntingan ini. Jika penulis perhatikan berita yang ditulis wartawan dan telah lolos seleksi terlihat masih sangat acakacakan serta tidak menentu susunan beritanya bahkan, sebagian bahasanya masih sulit untuk dimengerti dan penggunaan kaidah bahasa Indonesiannya juga masih banyak yang belum sempurna.

Oleh karena itu, Solopos melakukan berbagai upaya dalam teknik penyuntingan berita sehingga beritaberita yang dihasilkan bisa berkualitas. Baik dari segi penulisan maupun data dan faktanya. Namun dari beberapa contoh berita yang telah melewati proses penyuntingan yang dilakukan redaktur (editor) Harian Umum Solopos. Jika penulis perhatikan, teliti, dan analisa ternyata masih ditemukan beberapa kesalahan. Bahkan sebagian besar kesalahan itu merupakan kesalahan yang bersifat urgen (penting) dalam hal teknik menyunting pada media harian (cetak). Oleh karena itu, dalam penganalisaan ini penulis mengklasifikasikan penyuntingan menjadi tujuh kelompok sesuai penelitian yang penulis lakukan, yaitu: 
Pertama, kesalahan-kesalahan faktual

yang menyangkut kesalahan dalam menulis, baik mengenai kata-kata atau kalimat, nama, jabatan, gelar, nama tempat, alamat, dan lainlainnya. Penulis menilai, dampak dari kesalahan penulisan akan kecil jika kesalahan tulis itu hanya terjadi pada kata-kata pendukung atau kata biasa seperti, merupakan menjadi merupkan, tangkapan menjadi tangkap. Tapi, lain ceritanya ketika kesalahan dalam penulisan terjadi pada nama orang, gelar maupun nama instansi/perusahaan. Tentu akan berdampak fatal bagi media yang mempublikasikan beritanya itu. Bahkan, bisa jadi media bersangkutan dituntut/dimintai hak jawabnya oleh obyek pemberitaannya. Dan ini tentu tidak baik/bagus bagi sebuah media jika tidak sesegeranya untuk lebih memperketat dan memperbaiki kondisi ini.

Kedua, Penggunaan kaidah bahasa Indonesia seperti, ejaan masih ditemukan kesalahan-kesalahan dalam penyuntingan yang dilakukan redaktur/redpel. Karena bagaimanapun juga, bahasa yang digunakan media adalah bahasa
Indonesia yang baku dan sesuai Ejaan Yang Disempurnakan (EYD), hanya saja dalam berita langsung (straight news) memakai sifat yang lebih spesifik/khusus tetapi, tidak berarti bukan bahasa Indonesia. Karena, pada bahasa jurnalistik (terutama berita langsung) yang lebih ditekankan adalah sifat singkat, padat, lugas, namun tetap menarik. Seperti yang dikatakan Dr. Yus Badudu, "Bahasa surat kabar harus singkat, padat, sederhana, jelas, lugas, tetapi selalu menarik. Oleh sebab itu, kaidah yang menyangkut ejaan ini secara substansi tidak bisa ditawar-tawar lagi, kecuali telah menjadi kesepakatan baru yang telah diakui secara umum oleh setiap lapisan yang berwenang. Kesalahan penggunaan bahasa Indonesia ini, penulis temukan terbanyak kedua setalah kata mubazir. Kesalahan itu dapat ditemui pada pemberian tanda titik, koma, pada gelar, penempatan bahasa asing yang tidak dimiringkan, penempatan akronim yang bisa menimbulkan makna ganda/sistematika yang belum sempurna (kurang tepat) dalam penyuntingan/penulisan berita langsung, penulisan bahasa yang baku 
Situasi seperti ini harusnya tidak bisa dibiarkan atau dianggap ringan. Dampaknya akan sangat tidak menguntungkan bagi masyarakat/konsumen karena, setiap harinya koran ini (Solopos) dibaca oleh masyarakat. Selain itu, akan berdampak negatif bagi media yang bersangkutan maupun untuk kelangsungan bahasa Indonesia itu sendiri. Media, karena untuk keberlangsungannya (bertahan) dan bahasa Indonesia karena untuk diakui keabsahannya serta tidak membingungkan bagi audiens-nya.. Seharusnya dalam menyunting naskah berita, editor harus memiliki pengetahuan yang luas dalam penggunaan ejaan. Karena, jika editor salah dalam menggunakannya, maka pembaca akan mengikutinya.

Ke tiga, sebagai hati nurani surat kabar seorang editor harus tegas dalam penggunaan huruf besar, singkatan, dan pemilihan jenis huruf harus konsisten. Dibeberapa contoh yang penulis teliti dan amati ternyata dalam soal penulisan ada yang benar tetapi pada pada paragraf atau kalimat bahkan berita yang lainnya hal itu berbeda atau tidak benar. Ini menunjukan bahwa tidak konsistennya media ini.

\section{SIMPULAN}

Berdasarkan data yang diperoleh dan analisa yang penulis lakukan terhadap data di lapangan, tempat penulis membuat laporan ini, penulis dapat menyimpulkan sebagai berikut :

Pertama, dalam perusahaan penerbitan pers, seperti Solopos penyuntingan sangat perlu dilakukan. Karena, penyuntingan merupakan proses memperbaiki atau menyempurnakan tulisan (naskah berita) baik secara redaksional maupun substansialnya yang dilakukan seorang editor (redaktur penyunting) atau lebih ringkasnya menjadikan naskah berita menjadi copy berita. Secara redaksional, editor memperbaiki kata-kata supaya logis, mudah dipahami, dan tidak rancu. Sedangkan, substansialnya memperhatikan fakta dan datanya agar terjaga keakuratannya yang meliputi syarat-sayarat, nilai-nilai dan susunan sebuah berita (bersifat berita langsung). Dengan tujuan agar berita yang dibuat menarik dan mudah dipahami bagi pembaca. 
Kedua, sebelum proses penyuntingan dilakukan, yang tidak kalah pentingnya adalah proses seleksi (pemilihan naskah berita) yang sangat berkaitan dengan proses penyuntingan itu sendiri. Setelah itu baru dilakukan proses penyuntingan karena jika berita itu langsung dinaik cetakkan maka hasilnya kurang baik mengingat berita yang belum disunting masih sangat banyak kesalahan-kesalahan seperti, banyaknya kata-kata atau kalimat mubazir, struktur kalimat yang belum jelas dan penulisan berita yang tidak menarik. Setelah disunting oleh editor menghasilkan naskah berita yang mudah dipahami bagi pembacanya dan lebih ringkas dan langsung kepada pokok persoalannya.

\section{DAFTAR PUSTAKA}

Anwar, Rosihan H. 2004. Bahasa Jurnalistik Indonesia \& Komposisi. Yogyakarta: Media Abadi.

Ariningsih, Nur Endah, Sumarwati, Saddhono, Kundharu. 2012. Analisis Kesalahan

Berbahasa Indonesia dalam Karangan Eksposisi Siswa
Sekolah Menengah Atas. BASASTRA. 1 (1): 40-53.

Assegaf, Djafar. 1982. Jurnalistik Massa Kini. Jakarta: Ghalia Indonesia.

Djuroto, Totok. 2004. Manajemen Penerbitan Pers. Bandung: Rosda.

Ermanto. 2005. Menjadi Wartawan Handal \& Profesional (Panduan Praktis \& Teoritis). Yogyakarta: Cinta Pena.

Latsiya, Kartika Pandu, Baehaqie, Imam. 2016. Keefektifan Pembelajaran Menyunting Teks Ulasan Film dengan Model Pembelajaran Think Pair Share dan Model Pembelajaran Snowball Throwin pada Siswa Kelas XI SMA. Jurnal Pendidikan Bahasa dan Sastra. 5 (2): 4248.

Rondiyah, Arifa Ainun, Wardani, Nugraheni Eko, Saddhono, Kundharu. 2017. Pembelajaran Sastra melalui Bahasa dan Budaya untuk Meningkatkan Pendidikan Karakter Kebangsaan di Era MEA(Masyarakat Ekonomi 
ASEAN). Proceedings

Education and Language International Conference. 1 (1): 141-147.

Oktaria, Dinari, Andayani, Saddhono, Kundharu. 2017. Penguasaan Kalimat Efektif sebagai Kunci Peningkatan Keterampilan Menulis Eksposisi. Metalingua. 15 (2): 165-177. Redaksional Harian Umum SOLOPOS.

Romli, Syamsul M, Asep. Jurnalistik

Terapan

(Pedoman

Kewartawanan
Kepenulisan). 2005. Bandung: Batic Press.

Romli, Syamsul M, Asep. 2005. Jurnalistik Praktis untuk Pemula (Edisi Revisi). Bandung: PT. Remaja.

Soehoet, Hoeta A. M. 2002. Seleksi, Penyuntingan dan Penataan Isi Sirat Kabar dan Majalah. Jakarta: IISIP.

Widodo. 1997. Teknik Wartawan Menulis Berita di Surat Kabar dan Majalah. Surabaya: Indah. 


\section{LAMPIRAN}

Contoh naskah berita yang lolos seleksi dan belum disunting/diedit :

\section{BAM Kelangkaan Elpiji (0402)}

Kelangkaan Elpiji Poltabes Bentuk Tim Penyelidik Pekanbaru-Sulitnya untuk mendapatkan gas elpiji dibeberapa kawasan Kota Pekanbaru belangkangan ini sangat dirasakan masyarakat.Berbagai asumsi pun merebak sampai akhirnya mencuat kelangkaan diduga akibat permainan para agen yang akan menaikan harga dari biasanya. Indikasi adanya penimbunan itu menjadi perhatian pihak yang berwajib. Bahkan Poltabes sendiri telah membentuk tim khusus penyelidik untuk mengetahui penyebab kelangkaan tersebut. "Kita sudah bentuk tim khususnya penyelidik dari Poltabes. Mereka yang kita libatkan itu berasal dari anggota Poltabes sendiri dan dibantu oleh beberapa polsek yang ada. Sebab kita menduga hal ini merupakan ulah dari para agen atau pihak lain yang sengaja untuk menaikan harga dari biasanya," Ujar Kapoltabes Pekanbaru Kombes Pol Syafril Nursal SH.,MH didampingi Kabag Ops Kompol Anis PS.Sik kepada Riau Mandiri,Minggu (3/2) kemarin.

Anis menambahkan,kelangkaan elpiji yang dirasakan masyarakat memang mendapat perhatian khusus.Berbagai informasi dan keluhan pun mengisi jumlah pesan yang masuk di pusat kendali informasi kepolisian PKIK Poltabes. Sehingga pihak Mabes Polri pun harus menurunkan kebijakan untuk mengatasinya. Sehingga Poltabes Pekanbaru langsung membentuk tim penyelidik. Beberapa Polsek yang ada telah diperintahkan untuk melakukan penyelidikan. Terutama mencari dan mengawasi beberapa agen elpiji yang berada dilingkungan mereka.Jika ditemukan kejanggalan dalam bentuk penimbunan maka segera ditindak tegas." Setiap Polsek yang ada dapat melaporkan kepada kita bila ada penemuan dilapangan. Tidak ada toleransi sebab mereka harus ditindak, 'tambah Anis,(BAM).

Contoh naskah berita yang sudah disunting/diedit:

\section{Poltabes Bentuk Tim Usut Kelangkaan Elpiji}

PEKANBARU-Kepolisian Kota Besar (Poltabes) Pekanbaru telah membentuk tim khusus penyelidik untuk mengusut kelangkaan gas elpiji yang terjadi di Kota Pekanbaru sejak beberapa minggu belakangan. Tim khusus penyelidik ini dibentuk Poltbes berdasarkan dugaan bahwa kelangkaan elpiji tersebut disebabkan adanya permainan oleh pihak agen atau pihak lainnya. Sebab, menurut pihak Pertamina pasokan elpiji untuk Pekanbaru sudah kembali stabil sejak 26 Januari lalu. "Kita 
sudah bentuk tim khusus penyelidik dari Poltabes. Mereka yang kita libatkan itu berasal dari anggota Poltabes dibantu beberapa anggota Polsek. Sebab kita menduga, kelangkaan ini merupakan ulah dari para agen atau pihak lain yang sengaja untuk menaikkan harga dari biasanya," kata Kapoltabes Pekanbaru Kombes Pol Syafril Nursal, didampingi Kabag Ops Kompol Anis PS, kepada Riau Mandiri, Minggu (3/2) kemarin. Anis menambahkan, kelangkaan elpiji yang menyusahkan masyarakat memang menjadi perhatian khusus Poltabes. Berbagai informasi dan keluhan dari masyarakat tentang kelangkaan elpiji tersebut masuk ke Pusat Kendali Informasi Kepolisian (PKIK) Poltabes. Pihak Mabes Polri pun, kata Anis, menginstruksikan kepada jajaran kepolisian turut membantu mengatasi kelangkaan elpiji.

Beberapa Polsek, menurut Anis, telah diperintahkan melakukan penyelidikan. Terutama mengawasi agen elpiji yang berada di lingkungan mereka. "Jika ditemukan kejanggalan dalam pendistribusian atau terjadi penimbunan, maka tidak ada toleransi, segera ditindak tegas," kata Anis. Berminggu Kelangkaan elpiji di Kota Pekanbaru telah terjadi sejak beberapa minggu lalu, sejak pertengahan Januari. Kelangkaan elpiji yang terjadi dari pertengahan hingga beberapa hari menjelang akhir Januari, menurut pihak Pertamina disebabkan berkurangnya pasokan elpiji dari Dumai karena terjadinya kerusakan pada kilang di Dumai tersebut. Menurut pihak Pertamina, setelah kilang Dumai kembali beroprasi normal, maka kelangkaan akan teratasi. Seperti dikatakan Sales Representatif Elpiji Wilayah Sumatera Barat, Riau dan Kepulauan Riau (Kepri), Romi Ryan Manahutu, Sabtu (26/1) lalu, mulai Sabtu (26/1), pasokan gas elpiji untuk Pekanbaru dan wilayah Riau daratan lainnya, kembali stabil, karena kilang elpiji di Dumai kembali beroperasi normal.

"Kelangkaan elpiji beberapa hari terakhir disebabkan kurangnya suplai elpiji dari kilang Dumai karena mengalami kerusakan. Namun mulai besok, kilang Dumai akan kembali beroperasi normal. Besok kita suplai 56 ton elpiji dari kilang Dumai,” kata Romi ketika itu. Dengan dipasoknya 56 ton elpiji dari kilang Dumai, kata Romi, maka jumlah stok elpiji di Stasiun Pengangkutan dan Pengisian Bulk Elpiji (SPPBE) Pasir Putih akan menjadi 66 ton, karena 10 elpiji masih masuk dari kilang Medan, Sumatera Utara. "Kita harapkan, dengan dipasoknya 56 ton, ditambah 10 ton, kesulitan mendapatkan elpiji di wilayah Riau daratan khususnya di Pekanbaru, bisa teratasi,"terang Romi.bam

Keterangan (permasalahan yang ditemukan) :

Alinea ke-2, baris ke-1, pada kata khusus penyelidikan, Poltabes, bahwa, tersebut, oleh merupakan kata yang mubazir dan sangat tidak ekonomi kata sekali. Padahal jika kata-kata tersebut dihilangkan tidak akan merubah maksud sebenarnya. 
Alinea ke-2, baris ke-3, pada kata "Sebab..."= (opini/interpretasi wartawan/redaktur)

Alinea ke-6, baris ke-1, pada kata sejak beberapa minggu lalu, kelangkaan elpiji yang terjadi dari pertengahan, beberapa hari, disebabkan, tersebut, menurut pihak pertamina, Dumai. (Merupakan kata-kata mubazir dan membosankan/kurang menarik).

Alinea ke-7, Sabtu (26/1) lalu, mulai Sabtu (26/1) = (kata mubazir)

Alinea ke-7, kata kembali membosankan, seharusnya diganti mulai atau yang lain tapi tidak merubah maknanya.

Paragraf ke-6, kata Pertamia seharusnya Pertamina $=$ (salah penulisan $)$

Alinea ke-6 sampai alinea ke-9, dalam berita yang sudah di sunting tidak ada dan beritanya sudah tidak aktual lagi (nilai jurnalistinya) dan bisa menimbulkan kontradiksi. 


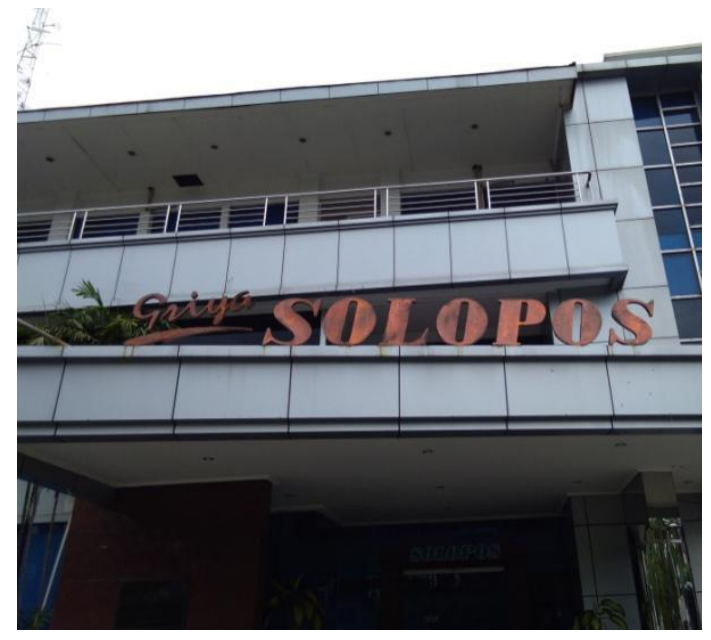

Gambar 1. Kantor SOLOPOS

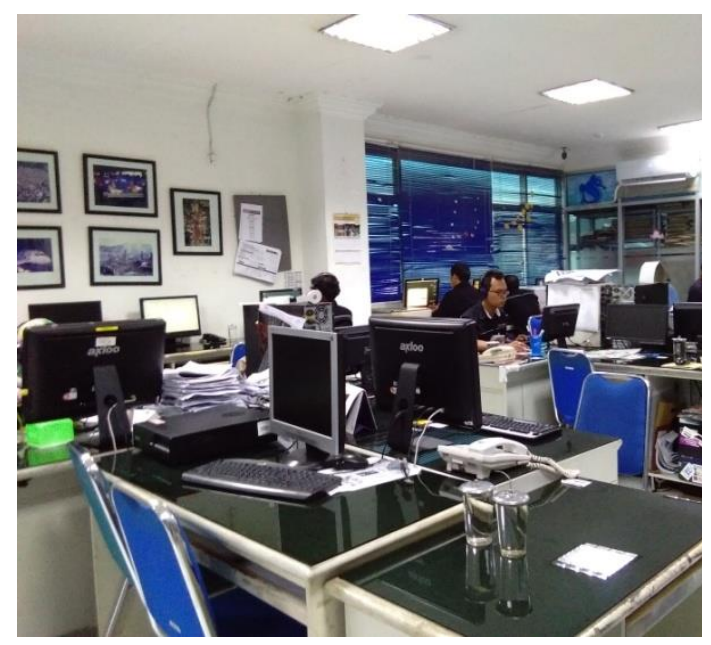

Gambar 2. Kantor Bagian Editor

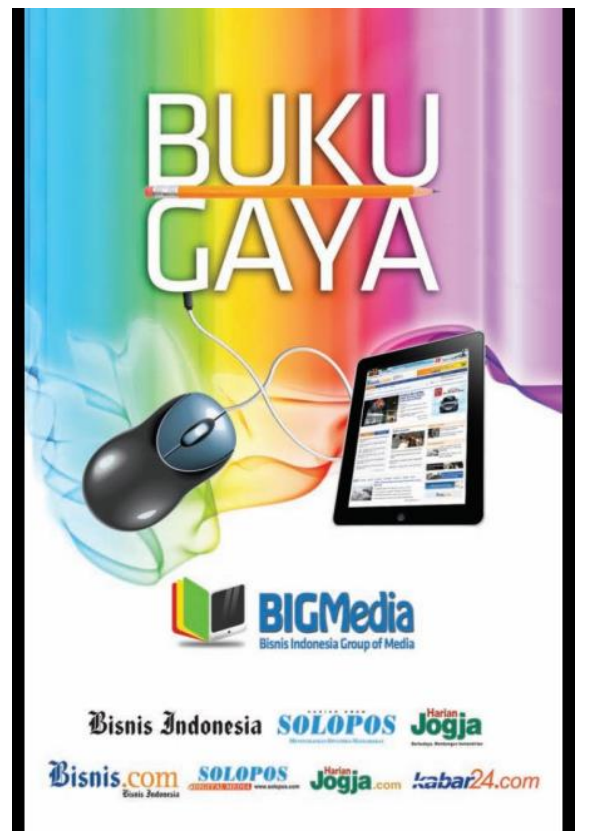

Gambar 3. Smpul Buku Gaya Selingkung Solopos

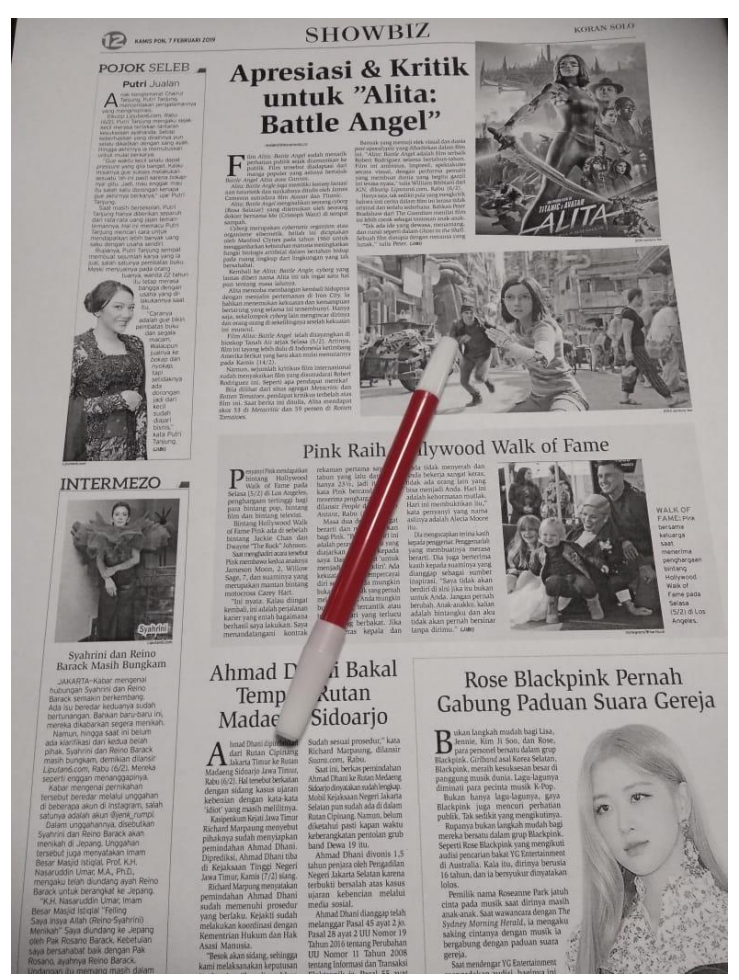

Gambar 4. Kondisi Naskah Sebelum

Dikoreksi 

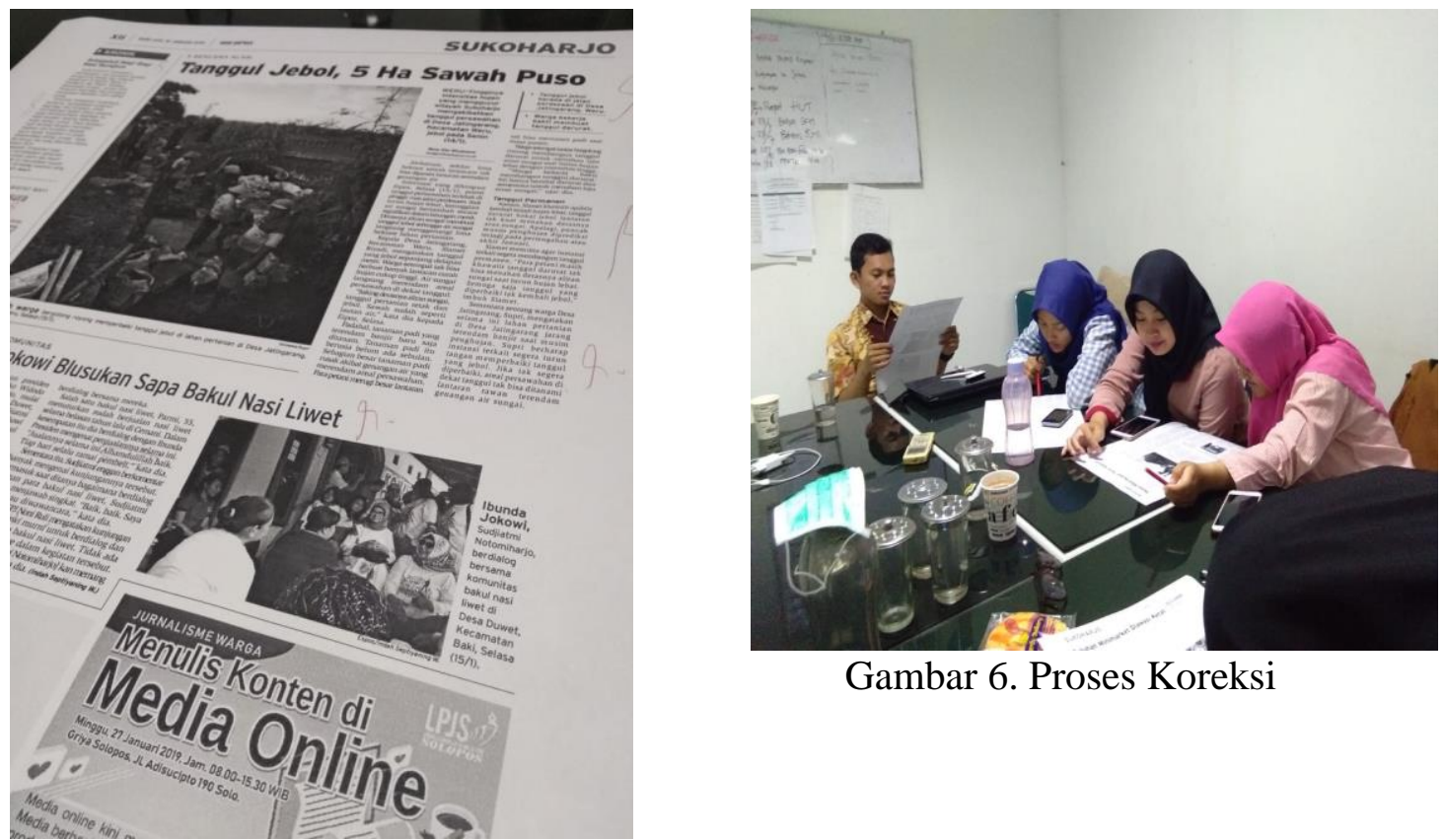

Gambar 6. Proses Koreksi

Gambar 5. Kondisi Naskah Setelah

Dikoreksi 